\title{
Susceptibility of Maize Inbreds and Incidence of Symptomless Infection by the Head Smut Pathogen, Sphacelotheca reiliana
}

\author{
S. J. Anderson and H. E. Simmons, Department of Plant Pathology and Microbiology, Iowa State University, Ames 50011; \\ R. D. French-Monar, Department of Plant Pathology and Microbiology, Texas A\&M AgriLife Extension Service, Amarillo 79106; and \\ G. P. Munkvold, Department of Plant Pathology and Microbiology, Iowa State University, Ames 50011
}

Accepted for publication 11 December 2015. Published 5 January 2016.

\section{ABSTRACT}

Anderson, S. J., Simmons, H. E., French-Monar, R. D., and Munkvold, G. P. 2016. Susceptibility of maize inbreds and incidence of symptomless infection by the head smut pathogen, Sphacelotheca reiliana. Plant Health Prog. 17:1-5.

A real-time PCR assay was used to compare seedling infection by Sphacelotheca reiliana, the causal agent of head smut, among five inbred genotypes representing low, moderate, and high susceptibility to the disease. Seeds were coated with teliospores and planted in autoclaved field soil in a growth chamber. Incidence of seedling infection at growth stage V3 differed between an inbred genotype of low susceptibility and those of moderate and high susceptibility, but did not differ between the high and moderately susceptible groups $(P<0.05)$. The real-time PCR assay was also used to compare infection status at early and late vegetative stages with observable symptoms in the field. We detected infection via real-time PCR in

\section{INTRODUCTION}

Head smut, caused by the fungus Sphacelotheca reiliana (Kühn) G.P. Clinton, is a widespread and economically important disease of maize (Zea mays L.). Inoculum is soilborne; the fungus infects maize seedlings through the roots and grows as a biotrophic endophyte behind the meristem. Infection generally proceeds without effecting noticeable change in plant growth until the plant reaches its reproductive stages. As the plant begins to switch from vegetative to reproductive development, the fungus invades the immature ear shoot tissues and begins to sporulate and destroys most of what would be the maize ear, creating masses of black fungal spores (sori) in place of the ears. Symptomatic plants typically produce no grain, so the disease can cause major yield losses (Martinez et al. 2002). Yield loss is proportional to disease incidence, which can reach $80 \%$ in individual fields (Frederiksen 1977). Losses in northern China, where the disease is common, have been estimated at 300,000 tons per year (Zhang et al. 2013a).

Genetic resistance is an important strategy for the prevention of head smut (Pataky 1999). A wide range of susceptibility or partial resistance has been observed across inbred lines, ranging from 0 to $>90 \%$ disease incidence (Stromberg et al. 1984; Whythe and Gevers 1987; Ali and Baggett 1990; Wang et al. 2008). The majority of studies seeking to identify maize genes conferring high degrees of resistance have concluded that resistance is quantitative, mostly additive, and highly complex, leading to the study of quantitative trait loci (QTL) for resistance. Several

Corresponding author: G. P. Munkvold. Email: munkvold@iastate.edu maize at both growth stages during field trials conducted in Texas and California but observed no disease symptoms (smutted ears or tassels). Notably, the fungus was present in up to $31 \%$ of the ear shoots in plots without disease symptoms. The real-time assay can be a useful tool for screening seedling-stage host resistance, and for better understanding the progress of infection in different maize genotypes. The field data suggest that asymptomatic infection is much more common than previously thought, and may have important implications for the epidemiology of this fungus under diverse plant resistance and growing conditions.

studies have sought to characterize QTL conferring resistance to head smut. Lübberstedt et al. (1999) identified groups of 3 and 8 QTL that explained $13 \%$ and $44 \%$ of resistance, respectively. The authors concluded that QTL primarily have minor or additive effects, but a few inbred lines displayed high levels of resistance over several years and locations, leaving open the possibility of major resistance genes. For instance, both Stromberg (1984) and Wang (2008) tested 'B73' and found it to be highly resistant and Stromberg (1984), Wang (2008), and Whythe and Gevers (1987) found 'Mo17' to exhibit a high level of resistance. Li et al. (2007) identified 5 major QTL conferring head smut resistance, three of which were also identified in the study by Lübberstedt (1999). Further studies such as Li et al. (2012) and Wang et al. (2012) have led to the identification of additional QTL and major genes for resistance.

In these and other studies on resistance to head smut, the phenotyping process is constrained by the fact that $S$. reiliana infection is undetectable until the reproductive stages of maize when disease symptoms generally appear. Due to the lack of visible symptoms during disease development, identification of genotypes with resistance to head smut requires lengthy field trials with high numbers of replications (Stromberg et. al. 1984; Frederiksen 1977). Many replications are required if naturally infested fields are used, due to highly heterogeneous spatial distribution of inoculum. In an attempt to reduce variability, artificial inoculation procedures using soil infested with teliospores have been developed which promote more uniform pathogen challenge across treatments. The pitfalls of artificially inoculating soil with teliospores of $S$. reiliana are that extremely large amounts of inoculum are generally needed (Stromberg et al. 1984), with the effect that head smut inoculum is then introduced into an area that may not have had previous inoculum, possibly 
rendering the newly infested soil undesirable for commercial maize production or other maize research plots. These methods are costly and time-consuming, and results can be difficult to interpret due to experimental variability. There is a need for more efficient and reliable screening of maize genotypes. An alternative assay, using an assessment of seedling infection, could greatly facilitate selection of resistant genotypes by providing more rapid and consistent results without the risk of unintentional pathogen spread in the field.

Accordingly, our objective was to evaluate a previously developed seedling assay (Anderson et al. 2016) for use in testing maize genotypes for resistance to $S$. reiliana in a laboratory bioassay.

\section{GROWTH CHAMBER INFECTION OF MAIZE INBRED SEEDLINGS}

Sori from smutted maize plants in Sacramento County, CA, were collected as a source of $S$. reiliana teliospores. The sori were sieved to separate the teliospores from plant vascular tissue and other plant debris, and these spores were collected in glass jars and shipped to Iowa under the conditions of APHIS-PPQ permit P526P-11-02346. Teliospores were stored at $4^{\circ} \mathrm{C}$ until they were needed, at which point they were surface sterilized according to the protocol of Bruckart and Eskandari (2002), and viability was checked according to the protocol of Osorio and Frederiksen (1998). Spores were observed under a compound microscope and were considered germinated if a promycelium or basidium was present; germination was consistently observed at a rate of $60 \%$ after three days.

Maize seeds of five different inbred genotypes (A619, B68, B73, Mo17, and Va26) were obtained from the USDA Germplasm Resources Information Network (GRIN). These inbreds were chosen because they represent low (A619, Va26), medium (B68), and high (B73, Mo17) levels of resistance to head smut based on their performance in previous research (Stromberg et al. 1984). Preliminary trials were conducted to optimize the concentration of inoculum for seed coating to maximize infection rates while maintaining emergence rates. Three concentrations of inoculum were tested: $10^{5}, 10^{6}$, and $10^{7}$ teliospores per seed. It was determined that a concentration of $10^{6}$ spores per seed was optimal for infection, and this was used in subsequent experiments. In order to target $10^{6}$ teliospores per seed as the inoculum load, $0.25 \mathrm{~g}$ teliospores were suspended in $10 \mathrm{ml}$ of a DAT (3\% dextrose w/v, 0.1\% agar w/v, 3 drops tween 20 per 100 $\mathrm{ml}$ total volume) solution. Surface-sterile seeds (100 g) of each of the five inbreds were placed into individual Ziploc bags with the spore suspension and the bags were lightly kneaded to ensure even seed coating. Under a sterile biosafety hood, each bag was opened to allow the spore suspension to dry and adhere to the seeds. To verify the inoculum load per seed, ten dried seeds were arbitrarily chosen from the bag and suspended in $10 \mathrm{ml}$ of water in a $50 \mathrm{ml}$ centrifuge tube with one drop of tween added. The tube was vortexed to dislodge spores from the seed coat; samples of the suspension were taken, spores were enumerated using a hemocytometer, and teliospores per seed were calculated.

Coated seeds were planted at a depth of $4 \mathrm{~cm}$ in autoclaved field soil in $150 \mathrm{~cm}^{3}$ cone-tainers (Cone-tainer Nursery, Canby, $\mathrm{OR}$ ) (one seed per cone-tainer) and placed in the growth chamber. The conditions inside the growth chamber were as follows: day temperature, $27^{\circ} \mathrm{C}$; night temperature, $24^{\circ} \mathrm{C}$; day length, $15 \mathrm{~h}$; and relative humidity, $70 \%$. Plants were given approximately $10 \mathrm{ml}$ of water on a daily basis and were grown for approximately 4 weeks until growth stage V3 (Abendroth et al. 2011), when they were uprooted and processed. The roots and crown tissue of the seedlings were cleansed of visible soil under running tap water and then surface disinfested by submersion in $0.525 \% \mathrm{NaOCl}$ solution with agitation for $2 \mathrm{~min}$. The plants were then rinsed twice in sterile water for $30 \mathrm{~s}$. Under a sterile biosafety hood, tissue samples were excised from the crown, mesocotyl, seminal root, and nodal root tissues. The crown tissue was sampled by removing a cross section of the stem approximately $0.5 \mathrm{~cm}$ in length just above the protrusion of the nodal roots. Mesocotyl samples were taken by removing a cross section approximately $0.5 \mathrm{~cm}$ in length halfway between the seed and the nodal root protrusion. Both the seminal and nodal root tissues were sampled by twisting all the roots of one type together and then removing a $0.5-\mathrm{cm}$ cross section near the root base.

Tissue samples were placed in individual $1.2-\mathrm{ml}$ wells in a 96well grinding plate (Fisher Scientific, Waltham, MA) and lyophilized at $-56^{\circ} \mathrm{C}$ and $0.002 \mathrm{mBar}$ for 1 to 2 days. A small metal ball was then placed in each well and the plate was placed in a tissue grinder (Geno/Grinder, SPEX SamplePrep, Metuchen, $\mathrm{NJ}$ ). The tissues were ground at $1000 \mathrm{rpm}$ for $1 \mathrm{~min}$ or until tissue was sufficiently powdered. To extract genomic DNA, a method similar to that described by Rogers and Bendich (1985) was employed. The method is as follows; $600 \mu$ of cetyltrimethylammonium bromide (CTAB) extraction buffer $(0.1 \mathrm{M}$ Tris- $\mathrm{HCl}$, $\mathrm{pH} 7.5,0.7 \mathrm{M} \mathrm{NaCl}, 10 \mathrm{mM}$ EDTA, 1\% CTAB) + 2\% 2mercaptoethanol was added to each well and then tubes were incubated at $65^{\circ} \mathrm{C}$ for $1 \mathrm{~h}$ and inverted every $10 \mathrm{~min}$. The liquid from each sample was drawn off and transferred to a sterile 1.5 $\mathrm{ml}$ microfuge tube. Six hundred microliters of $24: 1$

chloroform:isoamyl alcohol was added to each of these tubes and each tube was inverted several times. Each tube was centrifuged for $10 \mathrm{~min}$ at $13.2 \times 10^{3} \mathrm{rpm}$ and the upper layer of liquid was drawn off and transferred to a sterile $1.5 \mathrm{ml}$ microfuge tube. Six hundred $\mu \mathrm{l}$ of cold isopropanol was added to each of the tubes which were then centrifuged for $10 \mathrm{~min}$ at $13.2 \times 10^{3} \mathrm{RPM}$. From each tube, the supernatant was poured off and the DNA pellet was retained in the tube. The pellet was then washed with $70 \%$ ethanol and air dried. Once dry, the pellet was eluted in $200 \mu \mathrm{l}$ ultrapure water.

All PCR reactions were performed using primers and protocol described in Anderson et al. (2016) using an Applied Biosystems (Waltham, MA) StepOne Plus real-time PCR system and Applied Biosystems 96-well 0.2-ml plates. Twenty microliters total reaction volume was used per sample well $(2 \mu \mathrm{l}$ of sample DNA extract, $10 \mu 1$ Applied Biosystems SYBR Green PCR Master Mix, $0.07 \mu \mathrm{l}$ forward primer, $0.07 \mu \mathrm{l}$ reverse primer, $7.86 \mu \mathrm{l}$ ultrapure water). The PCR parameters were as follows: pre-cycle stage, 5 min at $95^{\circ} \mathrm{C}$; 40 cycles of denaturing, $1 \mathrm{~min}$ at $95^{\circ} \mathrm{C}$; and 40 cycles of annealing and extension, $30 \mathrm{~s}$ at $60^{\circ} \mathrm{C}$.

Plant tissue samples (seminal root, nodal root, mesocotyl, and crown) were analyzed separately by real-time PCR. Individual plants were considered infected if threshold amplification (based on $\mathrm{Ct}$ value) occurred for any one or more of the four types of excised plant tissue or of the ear shoot tissue. Analysis of variance was performed on infection incidence data using the SAS Ver. 9.3 (SAS Institute Inc., Cary, NC) software package with general linear models and Bonferroni corrections to detect significant differences among treatment means. Data were combined among repetitions of the same experiment.

$S$. reiliana infection was detected in all five inbred lines at incidences ranging from $47 \%$ to $79 \%$ in all three growth chamber trials (Fig. 1). Although the experiment was conducted three times, in the final trial the emergence rate for B68 was very low (possibly due to poor seed quality); therefore, we excluded the data for B68 from the third trial. Mo17 had significantly lower 
infection incidence (47\%) than A619 or Va26 (76\% and 78\%, respectively), but did not differ significantly from B68 or B73 (79\% and $60 \%$, respectively), nor did either of these two differ from A619 or Va26. Although B68 had apparently higher infection incidence than Mo17, this difference was not significant, possibly due to the exclusion of data from the third trial. The fungus was not detected in non-inoculated control treatments or in the PCR negative control (ultrapure water).

The incidences of infection we observed in all five maize inbreds $(47 \%$ to $79 \%$ ) were higher than those observed in field trials by Stromberg et al. (1984) (3\% to 56\%). This could be due to high inoculum loads and infection-conducive growth chamber conditions. However, these data are not directly comparable because our results reflect seedling infection incidence, which was not measured in the previous study; nor did we grow plants long enough in the growth chamber to observe symptoms. Incidences of infection in the seedling assay demonstrated a much narrower range between the most resistant and the most susceptible inbred, compared to the wider range of disease incidences among the same inbreds in the Stromberg et al. (1984) field study. In the seedling assay, the most resistant and susceptible inbreds were distinguishable, but the relatively narrower range of mean infection incidences was not ideal for separating most of the genotypes. A larger sample size may have provided greater power to detect significant differences, or additional testing with lower inoculum doses might improve the separation of these genotypes. Although we tested lower inoculum levels with a susceptible line (data not shown), we did not assess a range of inoculum levels against inbreds with partial resistance.

According to Stromberg et al. (1984), susceptible maize inbreds Va26 and A619 showed higher infection incidence (56\% and $49 \%$ incidence, respectively) than did resistant maize inbreds Mo17 or B73 (3\% and 6\% incidence, respectively) and B68 was moderately susceptible, showing 34\% disease incidence $(P<$ 0.05). Resistant inbred Mo17 showed lower (47\%, averaged across three trials) infection incidence than did susceptible lines Va26 or A619 (78\% and 76\%, respectively, averaged across three trials) $(P<0.05)$, which is consistent with the field data. B68 and
B73 did not differ from either the "resistant" or "susceptible" lines $(P<0.05)$ although B68 did have a much higher average (79\%) incidence than Mo17. Both studies identified Va26 as highly susceptible and Mo17 and B73 as the most resistant, but the rankings of B68 and A619 differed between the two studies. There was a significant linear correlation for the mean infection incidence data from the two studies $(R=0.89 ; P=0.0429)$, but the Spearman rank correlation was not significant $(R=0.70 ; P=$ 0.1881 ), probably because of the B68 and A619 rankings, as well as the low number of observations.

\section{SYMPTOMLESS INFECTION OF MAIZE PLANTS IN FIELD TRIALS}

Field trials were conducted in Texas in 2012 and 2013 and in California in 2013. The Texas plots were located in Halfway, Hale County, and the California plots were located in Yolo County near Woodland, CA. Both locations had a history of head smut. Two treatments using seed of a susceptible hybrid (N58L-3000GT, Syngenta Seeds, Stanton, MN) were compared in the Texas field plots: (1) seeds coated with spore suspension at a rate of $10^{6}$ spores per seed; and (2) non-inoculated seed planted into soil previously infested with teliospores of S. reiliana. Standard fertilization practices were used, and four replicate plots of each treatment were planted with two 17.5 -ft rows per replicate and 80 plants per row. Twenty-five plants were randomly sampled from each plot at growth stage V3 and VT for evaluation of infection by real-time PCR. Growth stage V3 samples were taken by uprooting whole plants and sampling the tissues as described for the growth chamber trials. Growth stage VT plants were sampled by removing the ear shoot and excising $0.5 \mathrm{~cm}$ of tissue at the tip of the immature cob. After healthy plants reached stage R5, plots were scouted to observe and record the incidence of head smut symptoms.

The California field plots were naturally infested and seeds of hybrid TA-685-02 were planted into soil known to be previously infested with $S$. reiliana. There were 14 replicate plots, $6.1 \mathrm{~m}$ long, with 8 rows spaced $76 \mathrm{~cm}$ apart. Irrigation and fertilization were provided by subsurface drip tape, and standard practices were used for fertilization and irrigation amounts; weeds were

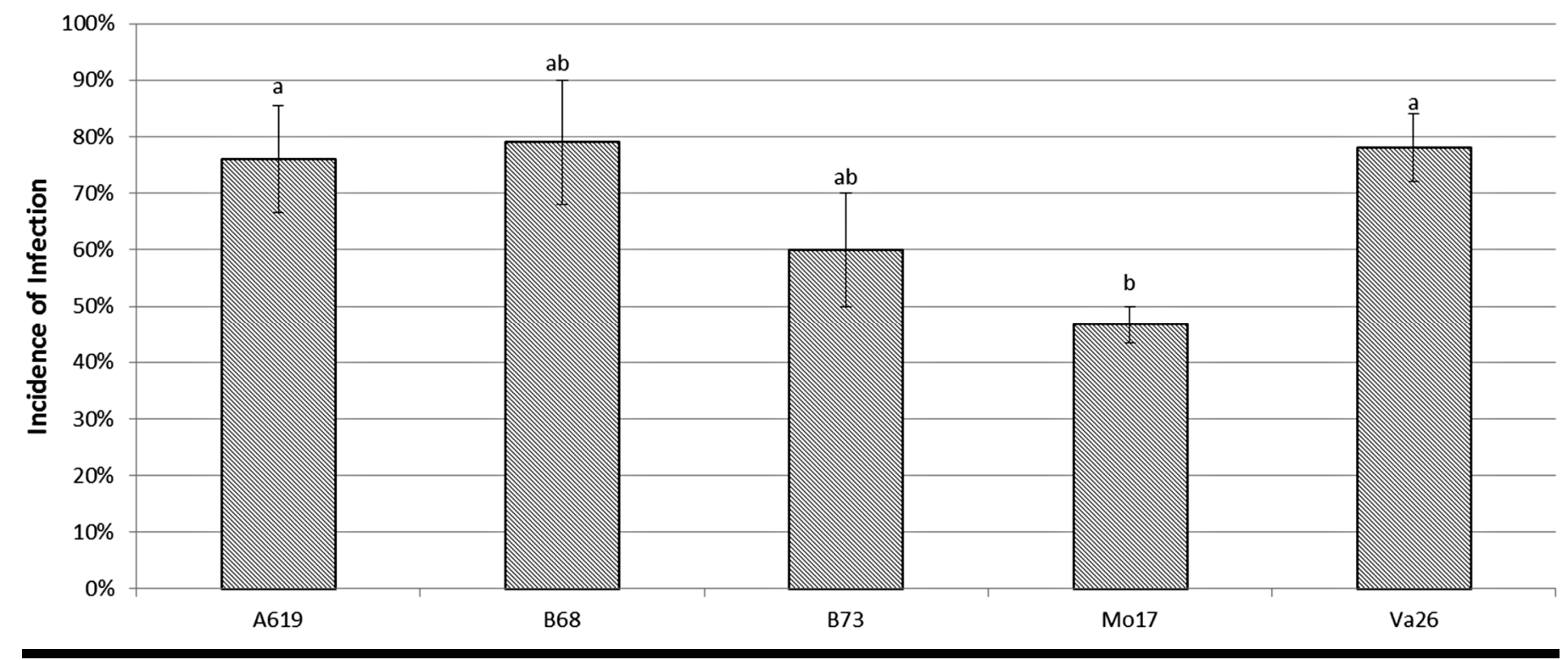

FIGURE 1

Sphacelotheca reiliana infection detected by real-time PCR in five different maize inbred lines. Bars represent the averages of three growth chamber trials $(n=60$ plants per inbred); those marked with the same letters were not significantly different $(a=0.05)$. 
controlled with a pre-emergence application of S-metolachlor (Syngenta Crop Protection) applied according to label recommendations. Sampling time differed from the Texas trials, with the first samples taken at growth stage V6 and the second sample set at VT. Ten plants were sampled from each of the 14 plots for both V6 and VT sampling times. Samples were processed in the same manner as the Texas field trials. After the plants reached stage R5, plots were scouted to observe and record the incidence of head smut symptoms.

Tissue samples from both field trials were shipped overnight to Iowa and subjected to real-time PCR analysis as already described.

In all three field trials, $S$. reiliana was detected in all the tissues types tested, both in seedlings at stage V3 and V6 and in the ear shoots at growth stage VT (Table 1). Higher infection incidences were observed in Texas than in California. Mean seedling infection incidence in Texas ranged from $28 \%$ in the noninoculated treatment in 2013 to $54 \%$ in the inoculated treatment in 2012, and ear shoot infection incidence ranged from $13 \%$ in the non-inoculated treatment in 2013 to $31 \%$ in the inoculated treatment in 2013. Means were significantly higher $(P<0.05)$ in the inoculated treatment compared to the non-inoculated treatment in Texas. In California, mean incidences of seedling and ear shoot infection were $11 \%$ and $8 \%$, respectively. The fungus was not detected in negative control wells in the PCR reactions. No head smut symptoms were observed in any of the field plots at either location during the trials.

The field trials were conducted with the purpose of assessing the relationship between the incidence of $S$. reiliana infection detected in tissue samples and the incidence of observed disease symptoms (i.e., smutted tassels or ears). However, no symptoms were observed in either year or location, and within both treatments, even when greater than $50 \%$ of seedlings and $30 \%$ of ear shoots were infected. The $95 \%$ confidence interval for ear shoot infection incidence in the lowest-incidence plots (California) was $4.0 \%$. Every plant in these plots ( $>4000$ plants total) was assessed for symptoms, and even if disease incidence were as low as $4.0 \%$, the probability that at least one diseased plant would have been found is greater than $99.9 \%$. Therefore, we are confident that the lack of symptom observation was not due to sampling error. Although Ustilago maydis and $S$. reiliana can cooccur, we did not observe any symptoms of $U$. maydis in the fields, tissues were surface disinfested, sampling occurred prior to silk emergence [and therefore prior to any $U$. maydis infection that may have occurred in ears (Pataky 1999)] and U. maydis does not systemically infect maize plants. Additionally, the amplified sequence does not have high homology with U. maydis $(\leq 55 \%)$.

The discrepancy between infection status and symptom appearance suggests that host or environmental factors suppressed symptom expression in some infected plants. Similar observations have been reported by Zhao et al. (2015) and Konlasuk et al. (2015). This suppression may have affected fungal spread within the plant so that the ears were not affected, even though the fungus was detected at V3, V6, and ear shoots at VT. Recent studies (Ghareeb et al. 2011; Zhang et al. 2013; Zuther et al. 2011) have examined the disease progression of $S$. reiliana and the resulting smut symptoms in maize, particularly regarding the timing of $S$. reiliana invasion of the inflorescence tissues. Evidence from these studies suggests that timing of fungal invasion of floral tissues is absolutely critical for the expression of smut symptoms; invasion of inflorescence tissue prior to floral transition inhibits the ability of the fungus to interfere with ear development and can lead to a lack of symptom expression. Craig
TABLE 1

Incidence of Sphacelotheca reiliana infection and observed symptoms of head smut in maize field trials in Texas and California.

Incidence of Infection (\%)

\begin{tabular}{|c|c|c|c|}
\hline Location & $\begin{array}{c}\text { Root and Crown } \\
\text { Tissue }\end{array}$ & Ear Shoots & $\begin{array}{l}\text { Observed } \\
\text { Symptoms }\end{array}$ \\
\hline $\begin{array}{l}\text { Texas } 2012 \\
\text { Inoculated } \\
\text { Natural } \\
\text { infestation }\end{array}$ & $\begin{array}{l}54(43.7-64.0) \\
30(21.2-40.0)\end{array}$ & $\begin{array}{c}30(21.2-40.0) \\
-\end{array}$ & $\begin{array}{l}0 \\
0\end{array}$ \\
\hline $\begin{array}{l}\text { Texas } 2013 \\
\text { Inoculated } \\
\text { Natural } \\
\text { infestation }\end{array}$ & $\begin{array}{l}47(36.9-57.2) \\
28(19.5-37.9)\end{array}$ & $\begin{array}{c}31(22.1-41.0) \\
13(7.1-21.2)\end{array}$ & $\begin{array}{l}0 \\
0\end{array}$ \\
\hline $\begin{array}{l}\text { California } 201 \\
\text { Natural } \\
\text { infestation }\end{array}$ & $11(6.1-17.0)$ & $8(4.0-13.6)$ & 0 \\
\hline \multicolumn{4}{|c|}{$\begin{array}{l}{ }^{\mathrm{a}} \text { Incidence of infection measured by real-time PCR based on four } \\
\text { replications of } 25 \text { plants each in Texas and } 14 \text { replications of } 10 \text { plants } \\
\text { each in California. Root and crown tissue was sampled at growth } \\
\text { stage V3 (TX) or V6 (CA). Ear shoot tissue was sampled at growth } \\
\text { stage VT. Numbers in parentheses are } 95 \% \text { confidence intervals for } \\
\text { infection incidence. Data for ear shoots was not collected for naturally } \\
\text { infested plots in 2012. } \\
{ }^{b} \text { Smutted ears and tassels observed during field scouting. }\end{array}$} \\
\hline
\end{tabular}

and Frederiksen (1992), in a study of $S$. reiliana on sorghum, demonstrated that in resistant genotypes with reduced disease incidence, plants were infected but the pathogen did not reach the apical meristem. Similarly, Zhang et al. (2013) showed that invasion of maize inflorescence tissue prior to floral transition led to a reduction of symptom expression.

The PCR assay used in this study has the ability to detect $S$. reiliana presence within maize tissue and differentiate incidences of infection among maize lines. Because infected plants do not always display symptoms, this assay, as it was applied in this study, cannot be used to predict disease levels. However, it can serve as a useful tool as a preliminary screen to identify genotypes with seedling resistance to $S$. reiliana. Resistance mechanisms to $S$. reiliana may function by reducing root infection at the seedling stage (Zhang et al. 2013a) or by inhibiting the development of endophytic infections at later stages (Zhao et al. 2015). In addition, further research with this PCR assay may elucidate whether quantities of $S$. reiliana DNA in plant tissues are significantly correlated with symptom expression. Given that $S$. reiliana can infect maize without producing smut symptoms in the inflorescences, research to quantify $S$. reiliana DNA in different plant tissues at various growth stages will enhance understanding of the spatial and temporal activity of resistance mechanisms within the plant (Zhao et al. 2015). Plants infected with $S$. reiliana do not necessarily show symptoms such as smutted ears or tassels at maturity. Therefore, the possibility exists for the pathogen to survive in crop residue as mycelium and cause disease in a field that did not show symptoms in the previous maize crop. This could especially be a risk if maize is planted two or more years in a row, a practice that is not uncommon for several areas of Texas and other states. To our knowledge, this has not previously been reported, and will have implications in future research on the head smut pathosystem and may be an important factor in the epidemiology of the disease. 


\section{LITERATURE CITED}

Abendroth, L., Elmore, R., Boyer, M., and Marlay, S. 2011. Corn growth and development. PMR 1009, Iowa State Univ. Ext., Ames.

Ali, A., and Baggett, J. 1990. Inheritance of resistance to head smut disease in corn. J. Amer. Soc. Hort. Sci. 115:668-672.

Allan, R. F., and Duran, R. 1979. The influence of aging on teliospore germination. Plant Dis. Rep. 63:841-842.

Anderson, S. J., Simmons, H. E., and Munkvold, G. P. 2016. Real-time PCR assay for detection of Sphacelotheca reiliana infection in maize (Zea mays L.) seedlings and evaluation of seed treatment efficacy. Plant Dis. 99:1847-1852.

Bruckart, W. L., and Eskandari, F. 2002. Factors affecting germination of Puccinia jaceae var. solstitialis teliospores from yellow starthistle. Phytopathology 92:355-360.

Chen, Y., Chao, Q., Tan, G., Zhao, J., Zhang, M., Ji, Q., and Mingliang, X. 2008. Identification and fine-mapping of a major QTL conferring resistance against head smut in maize. Theor. Appl. Genet. 117:12411252.

Craig, J., and Frederiksen, R. A. 1992. Comparison of sorghum seedling reactions to Sporisorium reilianum in relation to sorghum head smut resistance classes. Plant Dis. 76:314-318.

Frederiksen, R. A. 1977. Head smuts of corn and sorghum. Pages 89-105 in: Proc. of the 32nd Annual Corn Sorghum Res. Conf. Am. Seed Trade Assoc., Washington, DC.

Ghareeb, H., Becker, A., Iven, T., Feussner, I., and Schirawski, J. 2011. Sporisorium reilianum infection changes inflorescence and branching architectures of maize. Plant Physiology. 156:2037-2052.

Konlasuk, S., Xing, Y., Zhang, N., Zuo, W., Zhang, B., Tan, G., and Xu, M. 2015. ZmWAK, a quantitative resistance gene to head smut in maize, improves yield performance by reducing the endophytic pathogen Sporisorium reiliana. Mol. Breeding 35:174. DOI 10.1007/s11032-0150325-2.

Li, W., Xu, X., Li, G., Guo, L., Wu, S., Jiang, Y., Dong, H., Weng, M., Jin, D., Wu, J., Ru, Z., and Wang, B. 2012. Characterization and molecular mapping of $R s r R$, a resistant gene to maize head smut. Euphytica 187:303-311.

Li, X., Wang, Z., Gao, S., Shi, H., Zhang, S., George, M., Li, M., and Xie, C. 2007. Analysis of QTL for resistance to head smut (Sporisorium reiliana) in maize. Field Crops Res. 106:148-155.
Lübberstedt, T., Xia, X., Tan, G., Liu, X., and Melchinger, A. 1999. QTL mapping of resistance to Sporisorium reiliana in maize. Theor. Appl. Genet. 99:593-598.

Martinez, C., Roux, C., Jauneau, A., and Dargent, R. 2002. The biological cycle of Sporisorium reilianum f. sp. zeae: An overview using microscopy. Mycologia 94:505-514.

Osorio, J. A., and Frederiksen, R. A. 1998. Development of an infection assay for Sporisorium reilianum, the head smut pathogen on sorghum. Plant Dis. 82:1232-1236.

Pataky, J. K. 1999. Common smut. Pages 33 in: Compendium of Corn Diseases, 3rd Ed. D. G. White, ed. APS Press, St. Paul, MN.

Potter, A. 1914. Head smut of sorghum and maize. J. Agric. Res. 2:339-371.

Rogers, S., and Bendich, A. 1985. Extraction of DNA from milligram amounts of fresh, herbarium and mummified plant tissues. Plant Mol. Bio. 5:69-76.

Stromberg, E., Stienstra, W., Kommedahl, T., Matyac, C., and Windels, C. 1984. Smut expression and resistance of corn to Sphacelotheca reiliana in Minnesota. Plant Dis. 68:880-884.

Wang, M., Yan, J., Zhao, J., Song, W., Zhang, X., and Xiao, Y. 2012. Genomewide association study (GWAS) of resistance to head smut in maize. Plant Sci. 196:125-131.

Wang, Z., Li, X., Xie, C., Li, M., Hao, Z., George, M., Xiao, M., Gao, S., and Zhang, S. 2008. Genetic diversity in a collection of Chinese maize inbred lines for resistance to head smut caused by Sporisorium reiliana. Maydica 53:47-54.

Whythe, I., and Gevers, H. 1987. Diallel analysis of resistance of eight maize inbred lines to Sphacelotheca reiliana. Phytopath. 78:65-68.

Zhang, S., Gardiner, J., Xiao, Y., Zhao, J., Wang, F., and Zheng, Y. 2013. Floral transition in maize infected with Sporisorium reilianum disrupts compatibility with this biotrophic fungal pathogen. Planta 237:1251-1266.

Zhang, S., Xiao, Y., Zhao, J., Wang, F., and Zheng, Y. 2013a. Digital gene expression analysis of early root infection resistance to Sporisorium reilianum f. sp. zeae in maize, Mol. Genet. Genomics 288:21-37.

Zhao, X., Tan, G., Xing, Y., Wei, L., Chao, Q., Zuo, W., Lübberstedt, T., and $\mathrm{Xu}$, M. 2012. Marker-assisted introgression of $q H S R 1$ to improve maize resistance to head smut. Mol. Breeding 30:1077-1088.

Zhao, X., Ye, J., Wei, L., Zhang, N., Xing, Y., Zuoa, W., Chao, Q., Tan, G., and $\mathrm{Xu}, \mathrm{M}$. 2015. Inhibition of the spread of endophytic Sporisorium reilianum renders maize resistance to head smut. Crop J. 3:87-95

Zuther, K., Kahnt, J., Utermark, J., Imkampe, J., Uhse, S., and Schirawski, J. 2012. Host specificity of Sporisorium reilianum is tightly linked to generation of the phytoalexin luteolinidin by Sorghum bicolor. MPMI 25:1230-1237. 